\title{
von Willebrand factor antigen and plasminogen activator inhibitor in giant cell arteritis
}

\author{
Elisabeth Nordborg, Rune Andersson, Lilian Tengborn, Staffan Edén, Bengt-Åke Bengtsson
}

\begin{abstract}
Sixty three patients (51 women, 12 men) with giant cell arteritis were studied by serial analyses of von Willebrand factor antigen (vWF:Ag) concentration and plasminogen activator inhibitor activity. Their mean age at the time of diagnosis was 71 years. Two hundred and one randomly selected subjects from the general population, aged 75 years, served as controls.

The mean concentration of VWF:Ag in the patients with giant cell arteritis before the start of corticosteroid treatment was 2.63 (SD 1.35) IU/ml compared with $1.71(0.69) \mathrm{IU} / \mathrm{ml}$ in the general population. The vWF:Ag concentration slowly decreased and reached the control range about 18 months after the diagnosis. The vWF:Ag did not correlate with the clinical group of giant cell arteritis nor with the results of temporal artery biopsy. Flare ups and vascular complications were not indicated by the vWF:Ag.

Plasminogen activator inhibitor activity in the patients was not significantly different from that of the general population at any time.

It was concluded that the determination of vWF:Ag and plasminogen activator inhibitor activity is of limited clinical value in the diagnosis, prognosis, and monitoring of steroid treatment in patients with giant cell arteritis.
\end{abstract}

Department of

Rheumatology,

The University

of Göteborg,

41345 Göteborg, Sweden

E Nordborg

Department of Infectious Diseases,

The University

of Göteborg,

41345 Göteborg, Sweden

$R$ Andersson

Department of Internal

Medicine $\mathbf{I}$,

The University

of Göteborg,

41345 Göteborg, Sweden

L Tengborn

B-Å Bengtsson

Department of

Geriatrics,

The University

of Göteborg,

41345 Göteborg, Sweden

$S$ Edén

Correspondence to: Dr Nordborg.

Accepted for publication

16 May 1990
Giant cell arteritis is a vasculitis of unknown cause, characterised by granulomatous inflammatory lesions in medium sized and large arteries.

A large number of subjects with cranial symptoms have a positive temporal artery biopsy, whereas in those with pure polymyalgia rheumatica the temporal artery biopsy is positive in only a minority. ${ }^{1}$ In patients without histological signs of arteritis the diagnosis is based on clinical symptoms. A laboratory test which supports the diagnosis would be of great value as most patients require treatment with corticosteroids for several years.

The von Willebrand factor is a large multimeric glycoprotein synthesised by endothelial cells $^{2}$ and megakaryocytes. ${ }^{3}$ It is present in plasma, platelets, and endothelial cells. The von Willebrand factor acts as a carrier protein for coagulation factor VIII and it promotes platelet adhesion, probably by forming a molecular bridge between the subendothelium in a damaged vessel wall and the platelets. ${ }^{4}$ The von Willebrand factor may be released into plasma in patients with vasculitis and has been regarded as a reliable index of vascular damage. ${ }^{5}$

Increased concentration of VWF:Ag has been described in patients with giant cell arteritis, but the results are conflicting. ${ }^{67}$

The activity of the fibrinolytic system depends on the cleavage of plasminogen to plasmin by tissue plasminogen activators. Tissue plasminogen activator and its main inhibitor-plasminogen activator inhibitor of endothelial cell type-are, like the von Willebrand factor protein, synthesised in endothelial cells. ${ }^{8}{ }^{9}$ Patients with vasculitis have been found to have a decreased fibrinolysis. ${ }^{10}$ Plasminogen activator inhibitor has not been previously analysed in giant cell arteritis.

This study aimed at evaluating the clinical value of vWF:Ag and plasminogen activator inhibitor activity measurements in the diagnosis and long term follow up of patients with giant cell arteritis.

\section{Patients and methods}

PATIENTS

Sixty three patients (51 women, 12 men) with giant cell arteritis were studied. Their mean age at the time of diagnosis was $71 \cdot 3$ years (range $50-87)$. The follow up period was 1.5 years or more in 28 of the 63 patients. Of the remaining 35 , three were seen at diagnosis only, 22 for six months, and 10 for between seven and 17 months. The patients were diagnosed as having giant cell arteritis if a temporal artery biopsy showed arteritis, characterised by the histological finding of the interruption of the internal elastic membrane and the infiltration of mononuclear cells into the arterial wall. Giant cells were often found, but their presence was not required for diagnosis. In patients with negative histological findings the diagnosis of giant cell arteritis was accepted if they had the symptoms and signs of temporal arteritis or fulfitled the following clinical criteria of polymyalgia rheumatica, according to Bengtsson and Malmvall $^{1}$ : (a) pain and stiffness affecting at least two large groups of proximal musclesthat is, neck, shoulders - upper arms, hips and thighs, with a duration of symptoms of more than two weeks; (b) raised erythrocyte sedimentation rate (ESR) of more than $40 \mathrm{~mm} / \mathrm{h} ;(c)$ age of 50 years or more; (d) no clinical or laboratory evidence of infection, malignant disease, rheumatoid arthritis, systemic lupus erythematosus, or periarteritis nodosa; (e) a prompt and longlasting relief of symptoms after the start of corticosteroid treatment.

The patients with giant cell arteritis were 
divided into the following four clinical groups, which have been previously defined. ${ }^{1}$ (a) temporal arteritis; (b) polymyalgia rheumatica; (c) temporal arteritis and polymyalgia rheumatica; (d) general symptoms.

Most of the patients were admitted to hospital for a week when a general physical and laboratory examination was performed as well as a biopsy of one or both of the temporal arteries.

At the time of diagnosis prednisolone was given to all the patients in a single morning dose of $10-45 \mathrm{mg}$ (mean $34 \mathrm{mg}$ ) and reduced to the lowest maintenance dose on the basis of the clinical and laboratory response. The patients were followed up longitudinally for one to two years (mean 15 months). During the study 12 patients went into remission and were able to interrupt the corticosteroid treatment. The table gives further details of the patients.

\section{CONTROL POPULATION}

A longitudinal study of the elderly in Göteborg was started in 1971-72 with systematic sampling of the 70 year old population. In 1976/77 a new sample of 70 year olds was examined and in 1981-82 a third cohort was invited to participate in the study. The survivors of this cohort were re-examined at the age of 75 . The method of sampling as well as the design and performance of the study have been described previously. ${ }^{11-14}$

Blood samples were taken from a randomly selected subsample of these subjects (total 201, 104 women, 97 men) for vWF:Ag, plasminogen activator inhibitor, and fibrinogen measurements.

\section{LABORATORY METHODS}

All blood samples were drawn between 0730 and 1000 before the start of steroid treatment and at various intervals. Vacutainer tubes $(5 \mathrm{ml})$ containing $0.5 \mathrm{ml} 0.13 \mathrm{M}$ trisodium citrate were used (one part citrate and nine parts blood) and centrifuged immediately at $2000 \mathrm{~g}$ for 20 minutes. The plasma was kept frozen at $-70^{\circ} \mathrm{C}$ until analysed.

For the fibrinogen assay Vacutainer tubes containing $0.5 \mathrm{ml}$ of $0.13 \mathrm{M}$ trisodium citrate and $50 \mathrm{mg} \Sigma$-aminocaproic acid were used. ${ }^{15}$ Tubes containing serum and citrate were used for $C$ reactive protein (CRP) and ESR measurements.

von Willebrand factor antigen was assayed with an enzyme linked immunosorbent assay (ELISA). ${ }^{16}$ Microtitre plates were coated with rabbit antibody to human von Willebrand factor and conjugate $\mathrm{F}\left(\mathrm{ab}^{\prime}\right)_{2}$ horseradish peroxidase (both from Dakopatts, Copenhagen, Denmark) used for detection. Standard plasma from 20 donors (10 female, 10 male) was pooled and calibrated against the international standardlot 87/718 (NIBSC, London, England).

Plasminogen activator inhibitor activity of the endothelial cell type was determined with the reagent Spectrolyse (Biopool, Umeå, Sweden) in a two stage indirect enzymatic assay according to the manufacturer's instructions. In stage one a fixed amount of tissue plasminogen activator is added to the plasma sample and allowed to react with the plasminogen activator inhibitor present. In stage two the residual tissue plasminogen activator activity is measured by adding the sample to a mixture of gluplasminogen, polylysine, and chromogenic substrate. The plasminogen activator inhibitor content of the sample is the difference between the amount of tissue plasminogen activator added and the amount of tissue plasminogen activator found. One unit of plasminogen activator inhibitor activity is defined as the amount of plasminogen activator inhibitor that inhibits one international unit of human single chain tissue plasminogen activator as calibrated against the international standard of tissue plasminogen activator lot 83/517 (NIBSC, London, England).

Erythrocyte sedimentation rate was measured by the Westergren method. $\mathrm{C}$ reactive protein was analysed by a single radial immunodiffusion, and fibrinogen concentration was measured using fibrin coagulated plasma. The normal range of values at our clinical laboratory was ESR $<28 \mathrm{~mm} / \mathrm{h}$; CRP 0-10 $\mu \mathrm{g} / \mathrm{l}$; fibrinogen $2-4 \mathrm{~g} / 1$.

\section{STATISTICAL METHODS}

Correlations between variables were tested with Pitman's test ${ }^{17}$ in those cases in which one value per patient and variable was used-for example, sex, age, clinical group, and the result of the temporal biopsy or the value of a variable registered at the time of diagnosis. The same test was used for comparisons of vWF:Ag between patients and controls and for comparisons between patients with and without remission.

To eliminate the influence of a difference in sex distribution Mantel's test ${ }^{18}$ was used when comparing patients and controls with respect to plasminogen activator inhibitor.

von Willebrand factor antigen, plasminogen activator inhibitor, ESR, CRP, and fibrinogen were recorded several times during the follow up period. Correlation coefficients between

Clinical groups in 63 patients with giant cell arteritis

\begin{tabular}{|c|c|c|c|c|c|}
\hline \multirow{2}{*}{$\begin{array}{l}\text { Clinical } \\
\text { group }\end{array}$} & \multicolumn{3}{|c|}{ Number of patients } & \multirow{2}{*}{$\begin{array}{l}\text { Histologically } \\
\text { proved } \\
\text { arteritis }\end{array}$} & \multirow{2}{*}{$\begin{array}{l}\text { von Willebrand } \\
\text { factor antigen } \\
(I U / m l)\end{array}$} \\
\hline & Men & Women & Total (\%) & & \\
\hline $\begin{array}{l}\text { Temporal arteritis } \\
\text { Polymyalgia rheumatica } \\
\text { Temporal arteritis and polymyalgia rheumatica } \\
\text { General symptoms }\end{array}$ & $\begin{array}{l}3 \\
8 \\
1 \\
0\end{array}$ & $\begin{array}{r}11 \\
35 \\
4 \\
1\end{array}$ & $\begin{array}{rr}14 & (22) \\
43 & (68) \\
5 & (8) \\
1 & (2)\end{array}$ & $\begin{array}{r}13 \\
5 \\
3 \\
1\end{array}$ & $\begin{array}{l}2 \cdot 82 \\
2 \cdot 93 \\
2 \cdot 59 \\
1 \cdot 52\end{array}$ \\
\hline Total (No (\%)) & $12(19)$ & $51(81)$ & $63(100)$ & $22(35)$ & \\
\hline
\end{tabular}

${ }^{*}$ Mean concentration before the start of steroid treatment. 
vWF:Ag and the other variables were calculated for each patient. The coefficients obtained were used as a sample applied to the sign test in order to test the correlation within patients. All tests were two sided.

\section{Results}

Before the start of corticosteroid treatment the vWF:Ag was significantly higher $(\mathrm{p}<0.001)$ in patients (mean $2.63 \mathrm{IU} / \mathrm{ml}$ (range $1 \cdot 13-7 \cdot 40$ )) than in the general population $(1.71 \mathrm{IU} / \mathrm{ml}$ $(0 \cdot 12-5 \cdot 25))$. The concentrations of $\mathrm{vWF}: \mathrm{Ag}$ were significantly raised during the first year in patients compared with the control population. After 18-24 months the concentrations had decreased and were no longer different from those of the control population (fig 1).

The plasminogen activator inhibitor activity, on the other hand, only varied slightly with time and no significant difference was noted at any

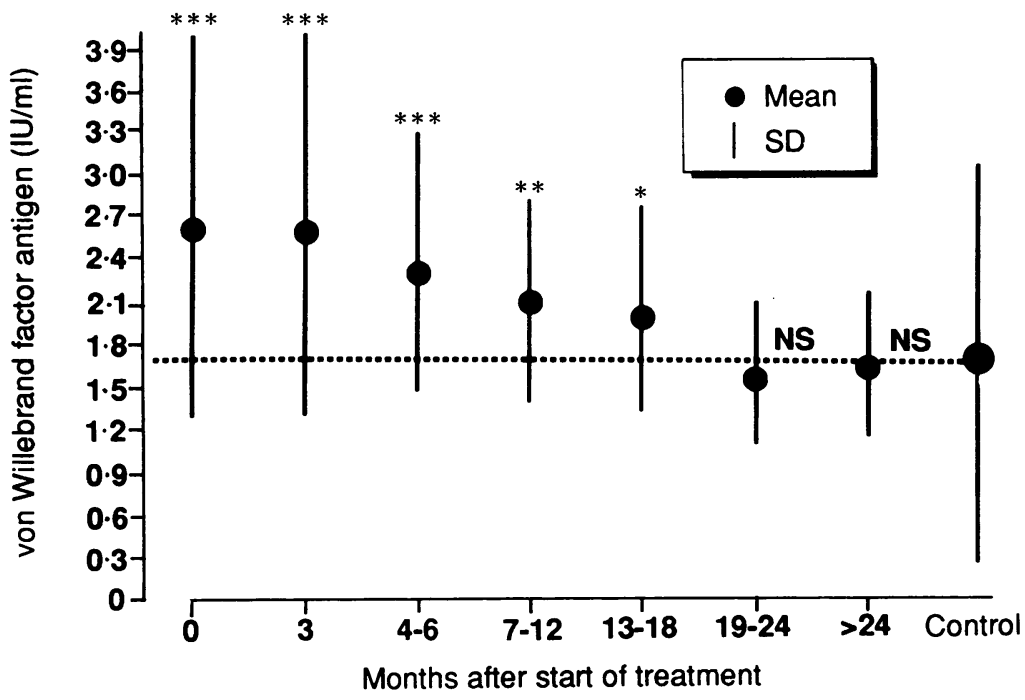

Figure 1 The von Willebrand factor antigen (vWF:Ag) concentration (mean (SD)) in relation to time after the start of corticosteroid treatment in 63 patients (51 women, 12 men) with giant cell arteritis compared with the concentration in a random selection of 201 subjects from the general population (mean (SD)). ${ }^{* * *} p<0.001 ;{ }^{* *} p<0 \cdot 01 ;{ }^{*} p<0.05$; $N S=$ not significant.

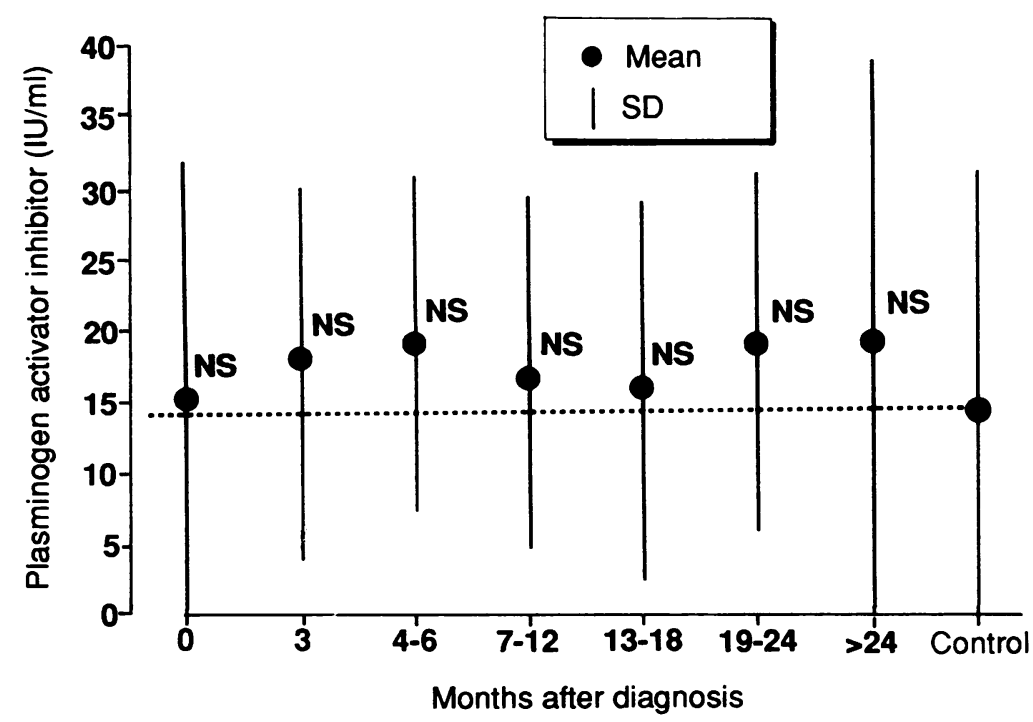

Figure 2 The plasminogen activator inhibitor activity (mean $(S D)$ ) in relation to time after the start of corticosteroid treatment in 63 patients with giant cell arteritis. The results were compared with those for 201 subjects from the general population (mean (SD)).

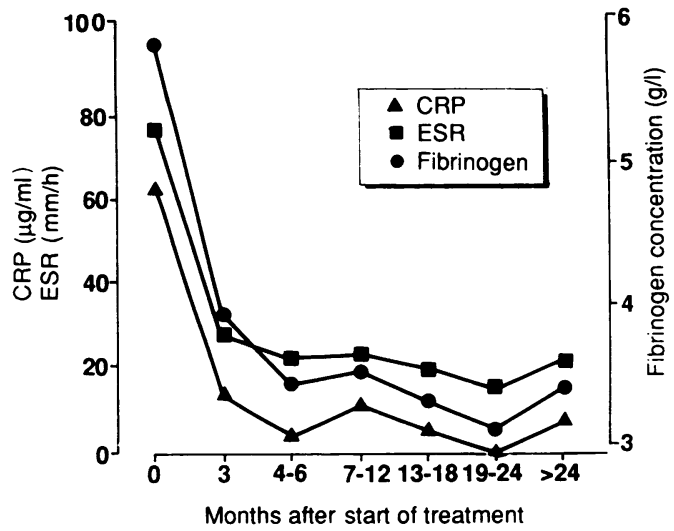

Figure 3 The $C$ reactive protein $(C R P)$, erythrocyte sedimentation rate $(E S R)$, and fibrinogen concentration in relation to time after the start of corticosteroid treatment in 63 patients with giant cell arteritis.

time compared with the general population (fig 2).

Age at diagnosis, sex, clinical group, and the result of the temporal artery biopsy did not significantly correlate with either $\mathrm{VWF}: \mathrm{Ag}$ or plasminogen activator inhibitor activity.

Erythrocyte sedimentation rate, CRP, and fibrinogen showed a rapid and longlasting response to corticosteroid treatment (fig 3). No significant within patient correlation was found between the vWF:Ag and CRP at any time of follow up. There was no correlation between vWF:Ag and either ESR or fibrinogen concentration.

A clinical flare up requiring an increased dose of corticosteroids occurred in 27 patients, of whom one woman had a severe form with a threatening necrosis of all the scalp. At flare up the mean vWF:Ag concentration was $2 \cdot 27$ IU/ml (range $1 \cdot 35-5 \cdot 30$ ) compared with $2 \cdot 23$ $\mathrm{IU} / \mathrm{ml}$ (range $1 \cdot 20-4.96$ ) (NS) two months before and $1.99 \mathrm{IU} / \mathrm{ml}$ (range $0.42-3.30$ ) (NS) two months after the flare up. The vWF:Ag concentration was unaffected in all but two patients and even in the severe case described above the VWF:Ag concentration remained in the range it had been in for more than one year-that is, $2 \cdot 80-3.00 \mathrm{IU} / \mathrm{ml}$. The ESR, on the other hand, increased in 17 of the 27 patients at the time of flare up.

Nine of the 63 patients still receiving corticosteroids had a threatening vascular occlusive episode during the follow up period: amaurosis fugax (two patients), pulmonary embolus (one), arterial embolus of the leg (one), deep vein thrombosis (one), myocardial infarction (one), hemiplegia (two), and transient ischaemic attack (one). At the time of diagnosis the mean vWF:Ag value in these nine subjects was $2 \cdot 34$ $\mathrm{IU} / \mathrm{ml}$ and did not differ significantly from the mean of all patients $(2 \cdot 63 \mathrm{IU} / \mathrm{ml})$.

In eight of the 63 patients the vWF:Ag concentration did not differ from that of the control population, neither at the time of diagnosis nor during the follow up period. In none could the corticosteroid treatment be withdrawn during the observation time.

Twelve subjects were able to discontinue corticosteroid treatment during a follow up 
period of 12-24 months (mean 19). The average vWF:Ag concentration at the time of clinical remission was $1.38 \mathrm{IU} / \mathrm{ml}$ (range $0.82-1.96$ )that is, within the same range as that of the control population and that of the total patient group.

A mean VWF:Ag concentration within the control range was also found in another 16 cases followed up for 18 months. In these subjects the clinical activity of the disease was low and they were still receiving corticosteroid treatment (2.5-5 mg prednisolone daily). When the steroids were reduced or withdrawn a flare up occurred.

\section{Discussion}

The vWF:Ag has been proposed as a marker of endothelial cell injury, ${ }^{5}$ but its use in clinical practice has not been established. In our patients with giant cell arteritis, the vWF:Ag concentration was significantly higher at the time of diagnosis than in the control group. This concentration decreased slowly and reached the same range as the controls only after 18-24 months. This is in accordance with previous studies. ${ }^{6} 719$

Our results show that the clinical value of measuring the vWF:Ag in these patients is slight as some patients had a vWF:Ag concentration within the control range during the whole follow up period despite a florid clinical disease, and others reached a normal vWF:Ag concentration at 18-24 months whether in clinical remission or with sustained clinical activity. von Willebrand factor antigen concentrations persistently within the control range were not associated with a shorter duration of the disease. The ESR was more helpful than the vWF:Ag concentration in detecting a flare up of the disease.

The concentration of the vWF:Ag did not differ in patients with biopsy proved giant cell arteritis compared with patients with a negative temporal biopsy. No significant differences were found between the clinical groups of giant cell arteritis. This conflicts with the studies of Persellin et al and Federici et al, ${ }^{6}{ }^{19}$ who found lower values of $\mathrm{VWF}: \mathrm{Ag}$ in the group with polymyalgia rheumatica.

No significant within patient correlation was seen between vWF:Ag and the acute phase reactants. This is in contrast with the positive correlation reported in patients with rheumatoid arthritis, though a positive correlation was not found in scleroderma or systemic lupus erythematosus. ${ }^{20}$ This may reflect differences in immunopathology. Pottinger et al recently found vWF:Ag to be an acute phase reactant with temporal rises correlated with those of CRP in response to acute infectious illnesses. ${ }^{21}$ In our patients with giant cell arteritis there were no individual correlations between CRP and vWF:Ag at any time. In Pottinger's study the peaks of CRP and vWF:Ag were reached some days apart, with vWF:Ag peaking first. ${ }^{21}$ As our patients were seen every one to three months a short transiently raised concentration of the VWF:Ag over a day or two would probably have been overlooked.
According to Jensen, however, in conditions such as diabetes mellitus, with or without overt angiopathy, the von Willebrand factor also is increased with a normal multimeric pattern. ${ }^{22}$ It has been assumed that such an increase is due to chronic stimulation of the endothelial cell. The increased vWF:Ag found in our patients with giant cell arteritis may be a similar phenomenon, though the releasing factor is still unknown.

$A$ raised vWF:Ag concentration thus supports but does not provide proof of an arteritis and cannot replace the temporal artery biopsy or other laboratory parameters as a routine investigation procedure.

We had expected increased plasminogen activator inhibitor activity in our patients because it acts as an acute phase protein. ${ }^{23}$ Surprisingly, the plasminogen activator inhibitor activity was not significantly higher, though the variation was considerable among both patients and controls. Jordan et al, however, noticed a deficient release of tissue plasminogen activator activity after venous occlusion in patients with systemic and cutaneous vasculitis. ${ }^{24}$ Belch and coworkers also found decreased activity when vessel damage occurred in patients with systemic lupus erythematosus, ${ }^{25}$ and in rheumatoid arthritis the tissue plasminogen activator activity correlated with general disease activity and not with evidence of vasculitis. The authors stated that measurement of tissue plasminogen activator activity would not be helpful as a marker of endothelial damage alone, and our findings suggest that determination of plasminogen activator inhibitor is similarly unhelpful as a screening test for detection of vascular lesions in these patients.

To conclude, the vWF:Ag concentration was increased initially in patients with giant cell arteritis, thereby suggesting some relation with the underlying arteritis. There was, however, a wide individual variation, and thus measurement of vWF:Ag concentration was not sufficiently useful for the diagnosis, the prediction of vascular complications, or for the prognosis or monitoring of treatment in patients with giant cell arteritis. For plasminogen activator inhibitor no correlation was found with the activity of giant cell arteritis.

The authors thank Anders Odén, Kungälv for statistical advice. This study was supported by a grant from the Medical Society of Göteborg. The control study is part of the Gerontological and Geriatric Population Study in Göteborg, Sweden (project group: B Steen (project leader), S Berg, H Djurfelt, S Edén, S Landahl, D Mellström) and supported by grants from the Delegation for Social Research within the Ministry of Health and Social Affairs, Social Research within the Ministry of Health and Social Affairs, the Göteborg Administration of Social Services, the Göteborg Medical Services Administration, the Swedish Medical Research
Council, the Göteborg Medical Society, and Stiftelsen Gamla Tiancil, the

1 Bengtsson B $\AA$, Malmvall B E. The epidemiology of giant cell arteritis including temporal arteritis and polymalgia rheumatica. Arthritis Rheum 1981; 24: 899-904.

2 Jaffe E A, Hoyer L W, Nachman R L. Synthesis of von Willebrand factor by cultured human endothelial cells. Proc Natl Acad Sci USA 1974; 71: 1906-9.

3 Nachman R, Levine R, Jaffe E A. Synthesis of factor VIII antigen by cultured guinea pig megakaryocytes. $\mathcal{f}$ Clin Invest 1977; 60: 914-21.

4 Ruggeri Z M, Zimmerman T S. von Willebrand factor and von Willebrand disease. Blood 1987; 70: 895-904.

5 Nusinow S R, Federici A B, Zimmerman T S, Curd J G. Increased von Willebrand factor antigen in the plasma of patients with vasculitis. Arthritis Rheum 1984; 27: 1405-10. 
6 Persellin S T, Daniels T M, Rings L J, Kazmier F J, Bowie E J W, Hunder G G. Factor VIII-von Willebrand facto in giant cell arteritis and polymyalgia rheumatica. Mayo Clin Proc 1985; 60: 457-62.

7 Ciompi M L, Marotta G, Puccetti L, et al. Behaviour of von Willebrand factor antigen in follow-up of polymyalgia theumatica/giant cell arteritis. Scand $\mathcal{F}$ R hewmatol 1988; 17 : 491-5.

8 Rijken D C, Wijngaards G, Welbergen J. Relationship between tissue plasminogen activator and the activators in blood and vascular wall. Thromb Res 1980; 18: 815-30.

9 Loskutoff D J, Edgington T S. Synthesis of a fibrinolytic activator and inhibitor by endothelial cells. Proc Natl Acad Sci USA 1977; 74: 3903-7.

10 Cunliffe W J, Dodman B, Roberts B E, Tebbs E M. Clinical and laboratory double-blind investigation of fibrinolytic therapy of cutaneous vasculitis. In: Davidson $J F$ Samema M M, Desnoyers P C, eds. Progress in chemical fibrinolysis and thrombolysis. Vol 1. New York: Raven Press, 1975: 325-33.

11 Eriksson B G, Mellström D, Svanborg A. A medical-socia intervention in a 70-year-old Swedish population. A general presentation of methodological experience. Compr Gerontol [C] 1987; 1: 49-56.

12 Nilsson-Ehle $\mathbf{H}$, Jagenburg $\mathbf{R}$, Landahl S, Svanborg A Westin J. Haematological abnormalities and reference intervals in the elderly. A cross-sectional comparative study intervals in the elderly. A cross-sectional comparative study of three urban Swedish population samples aged

81 years. Acta Med Scand 1988; 224: 595-604.
13 Nilsson-Ehle H, Jagenburg R, Landahl S, Svanborg A Westin J. Haematological abnormalities in a 75-year-old population. Consequences for health-related reference intervals. Eur f Haematol 1988; 41: 136-46.

14 Rinder L, Roupe S, Steen B, Svanborg A. Seventy-year-old people in Gothenburg. A population study in an industrialized Swedish city. Gen Med Scand 1975; 198: 397-407.
15 Nilsson I M, Olow B. Determination of fibrinogen and fibrinogenolytic activity. Thrombosis et Diathesis Haemhorrhagica 1962; 8: 297-310.

16 Ingerslev J. A sensitive ELISA for von Willebrand factor (vWF:Ag). Scand J Clin Lab Invest 1987; 47: 143-9.

17 Bradley J W. Distribution-free statistical tests. London: Prentice-Hall, 1968: 68-86.

18 Mantel N. Chi-square tests with one degree of freedom: extensions of the Mantel-Haenszel procedure. Fournal of the American Statistical Association 1963; 58: 690-700.

19 Federici A B, Fox R I, Espinoza L R, Zimmerman T S. Elevation of von Willebrand factor is independent of erythrocyte sedimentation rate and persists after glucocorticosteroid treatment in giant cell arteritis. Arthritis Rherom 1984; 27: 1046-9.

20 Gordon J L, Pottinger B E, Woo P, Rosenbaum J, Black C M. Plasma von Willebrand factor in connective tissue disease. Ann Rhewm Dis 1987; 46: 491-6.

21 Pottinger B E, Read R C, Paleolog E M, Higgins P G Pearson J D. von Willebrand factor is an acute phase reactant in man. Thromb Res 1989; 53: 387-94.

22 Jensen $T$. Increased plasma concentration of von Willebrand factor in insulin dependent diabetics with incipient nephropathy. BMF 1989; 298: 27-8.

23 Kluft C, Verheijen J H, Jie A H F, et al. The postoperative fibrinolytic shut-down: a rapidly reverting acute phase pattern for the fast-acting inhibitor of tissue-type plasminopattern for the fast-acting inhibitor of tissue-type plasminogen activator

24 Jordan J M, Bates Allen N, Pizzo S V. Defective release of tissue plasminogen activator in systemic and cutaneous vasculitis. Am J Med 1987; 82: 397-400.

25 Belch J J F, Zoma A A, Richards I M, McLaughlin K, Forbes C D, Sturrock R D. Vascular damage and factor VIII related antigen in the rheumatic diseases. Rheumatol Int 1987; 7: 107-11. 